\title{
Soil Physical Characteristics and Crop Productivity as Affected by Tillage in Rice-Wheat System
}

\author{
M. S. Kahlon ${ }^{1}$ \\ ${ }^{1}$ Department of Soil Science, Punjab Agricultural University, Ludhiana, India \\ Correspondence: M. S. Kahlon, Department of Soil Science, Punjab Agricultural University, Ludhiana 141004, \\ India. E-mail: dr.mskahlon@rediffmail.com
}

Received: September 3, 2014

Accepted: September 27, 2014 Online Published: November 15, 2014

doi:10.5539/jas.v6n12p107

URL: http://dx.doi.org/10.5539/jas.v6n12p107

\begin{abstract}
Tillage practices significantly influences soil physical characteristics and crop productivity. The infiltration characteristics, bulk density, porosity, penetration resistance, grain yield of rice and wheat were measured under no-till without residue (NT), roto-tillage (RT), and no-till with residue i.e. happy seeder (HS) in rice-wheat cropping system in sandy loam (SL) and loamy sand (LS) soils. For surface soil layer $(0-15 \mathrm{~cm})$ highest soil bulk density $\left(\mathrm{Mg} \mathrm{m}^{-3}\right)$ was recorded in HS (1.58) followed by RT (1.56) and NT (1.55) in LS soil. Soil porosity ranged from $40.6 \%$ to $41.2 \%$ under HS and RT, respectively for $0-15 \mathrm{~cm}$ depth in SL soil. The PR (K Pa) varied from 2412 (NT) to 2539 (HS) in SL. In LS soil PR (K Pa) varied from 2433 (NT) to 2603 (RT). Final infiltration rate (FIR) varied from 0.1 to $0.3 \mathrm{~cm} \mathrm{hr}^{-1}$ under RT and NT in SL soil, while, in LS soil FIR varied from 0.5 to 0.8 $\mathrm{cm} \mathrm{hr}^{-1}$ in RT and HS, respectively. Maximum rice grain yield ( $\left.\mathrm{t} \mathrm{ha}^{-1}\right)$ was recorded in RT (8.0) followed by NT (7.5) and HS (7.0) in SL soil. The corresponding rice yield ( $\left.\mathrm{tha}^{-1}\right)$ in LS was 6.5, 5.8 and 5.5 in RT, NT and HS, respectively. Wheat straw yield $\left(\mathrm{t} \mathrm{ha}^{-1}\right)$ ranged from 4.9 (NT) to 5.9 (HS) in SL soil. The wheat grain yield $\left(\mathrm{t} \mathrm{ha}^{-1}\right)$ was observed to be maximum in HS (4.5), followed by RT (4.0) and NT (3.9) in SL soil, while in LS soil the wheat grain yield $\left(\mathrm{t} \mathrm{ha}^{-1}\right)$ values were observed to be 2.7, 3.0 and 3.6 in NT, RT and HS, respectively. No significant effect of tillage and residue management practices was observed on grain yield of rice and wheat, however, significant changes were observed on water transmission characteristics and straw yields.
\end{abstract}

Keywords: soil physical properties, bulk density, penetration resistance, no-tillage, wheat

\section{Introduction}

Management and tillage practices strongly impact physical properties of the topsoil and the characteristics of the macropore system (Kumar et al., 2014). Soil moisture is an important factor affecting plant growth, especially under conditions of a limited water supply (Chintala et al., 2012a, 2012b). There are several practices (cover crop, mulch, residue incorporation) which reduce losses and increase moisture storage in the root zone, and happy seeder (HS) or no-till with residue is especially effective in enhancing soil moisture storage (Yuecun et al., 2008; Kumar et al., 2014). Long-term use of no-till without residue (NT) has adversely influenced soil physical properties with a notable decline in water transmission properties (Mahboubi et al., 1993). Soil tillage and residue application strongly influence soil properties, environment quality, and crop productivity (Keshavarzpour \& Rashidi, 2008; Ogban et al., 2008; Kumar et al., 2014). There is a strong interest and emphasis on adoption of conservation tillage like HS or no-till (NT) systems along with application of crop residue mulch for reducing soil erosion risks, improving soil quality by enhancing soil organic matter concentration and soil fertility, soil water storage capacity, infiltration rate, bio diversity, stability of ecosystem and energy use efficiency (Ogban et al., 2001; Iqbal et al., 2005; Kumar et al., 2014). Different tillage systems can change number, shape, continuity and size distribution of the pore network, which controls the ability of soil to store and transmit water and regulate aeration. Adoption of conservation tillage can improve available water capacity, which enhance edaphic environment and use efficiency of inputs (Khan et al., 2001; Khurshid et al., 2006; Kumar et al., 2014). The pore network in NT soil is usually more continuous because of biopores by earthworms, root channels and vertical cracks (Cannel, 1985). In contrast, residue retention or incorporation improves edaphological environment (Anikwe et al., 2004, 2007), moderates soil temperature (Sarkar \& Singh, 2007; Sarkar et al., 2007), increases soil porosity and water infiltration during intense rains (Gajri et al., 1994; Glab \& Kulig, 2008), and reduces runoff and soil erosion (Bhatt \& Khera, 2006; Prasad, 2014). Effects of tillage have been reported on penetration 
resistance, (Hermawan \& Bomke, 1997) bulk density (Dao, 1993; Cetin et al., 2005; Ozpiner \& Cay, 2005), infiltration characteristics (Azooz \& Arshad, 1998). However, results are inconsistent because of variation in soil properties and management practices. The nature and magnitude of tillage-induced changes in soil moisture properties also depend on soil type, tillage equipment, plowing depth, antecedent moisture content and climatic conditions (Chang \& Lindwall, 1990; Kumar et al., 2014). Mahboubi et al. (1993) reported that NT increased infiltration characteristics compared with conventional tillage after 28 years of same tillage systems on a silt loam soil in Ohio. Higher infiltration under NT with residue may be attributed to the higher volume of macropores, a favorable pore size distribution, and the continuity and connectivity of the macropore network (Ehlers, 1975; Logsdon et al., 1999; Frede et al., 1994; Shipitalo et al., 2000; Cameira et al., 2003). Under dry farming conditions, choosing an appropriate tillage method is important to minimizing risks of drought stress through decreasing losses by runoff and evaporation and increasing infiltration and soil moisture storage. Further, penetration resistance is more sensitive than bulk density to tillage treatments (Bauder \& Black, 1981; Hammel, 1989). Tillage systems which enhance water infiltration, increases soil moisture storage and improve hydro-physical properties are important to sustain agricultural practices (Brady \& Weil, 1999). Thus, it is important to understand how tillage alters soil moisture dynamics and other properties affecting it or vice-versa. Conservation tillage improves water availability to crops (Tessier et al., 1990), stores relatively more water in the soil profile (Husain et al., 1998; Kanwar, 1989) due to more crop residues at the soil surface and a lower losses by evaporation. Data on soil moisture dynamics is also needed to model and evaluate techniques for sustainable management of soil and water resources (Talaat, 2009). Conservation tillage improves water availability and thus crop productivity by minimizing evaporation, surface runoff and deep drainage losses (Tessier et al., 1990; Husain et al., 1998; Tripathi \& Chauhan, 2000). Mahboubi et al. (1993) reported that no-tillage could lead to excessive soil compaction resulting in poor plant growth and subsequently reduction in crop yield. Similar observations were also reported by other researchers (Carman, 1997; Hajabbasi \& Hemmat, 2000) in arid region. Sieling et al. (1998) reported higher wheat yields under NT in humid regions. Ghuman and Sur (2001) proposed that reduced tillage in conjunction with crop residue improves soil properties and subsequent wheat yield on sandy loam soils in the subtropical climate of north-western Punjab. A better understanding of conservation tillage performance over a wide range of soil and environmental conditions is required. Thus, a field study was conducted on different tillage and residue management practices to access their effects on soil physical properties and crop productivity in rice-wheat system.

\section{Materials and Methods}

\subsection{Site}

The field study was conducted on tillage and residue management experiment in rice wheat cropping system at experimental site of Department of Soil Science, Punjab Agricultural University, Ludhiana, India in sandy loam and loamy sand soil. The site is situated at $30^{\circ} 56^{\prime} \mathrm{N}$ latitude and $70^{\circ} 52^{\prime} \mathrm{E}$ longitude and is $247 \mathrm{~m}$ above mean sea level. The summer of the region is extremely hot and winters are severely cold.

\subsection{Experimental Design}

The experiment was laid out as a randomized complete block design, with three replications. The individual plot size was $15 \times 10 \mathrm{~m}$. In NT plots wheat was sown with no-till (NT) machine by removing whole paddy straw of previous crop, in roto-till (RT) plots whole of rice residue left after combine harvesting was incorporated in soil by rotavator operations and later on wheat was sown with ordinary drill and in third treatment i.e. HS (Happy Seeder) which was no-till practice with residue retention and the wheat crop was sown directly in standing rice stubbles and loose straw. This machine has special attachments to cut, cultivate and sow seed in single operation. However, rice was transplanted under puddled field conditions.

\subsection{Determination of Soil Bulk Density, Porosity, Penetration Resistance, Infiltration Characteristics and Soil Moisture Storage}

Soil bulk density was determined for 0-15 and 15-30 cm depths using the core method (Blake \& Hartage, 1986). Cores were wrapped with polythene sheets after cutting the extra soil on the top and the bottom of the core with sharp knife. To avoid any moisture loss from the samples, the cores were put into thermo-box and bring to lab immediately after sampling. The fresh weights of the cores were then recorded in the laboratory. To get moisture content value, a separate soil samples for the same depths were also brought in the polythene bags. Soil penetration resistance (PR) was measured by a hand-held digital cone-tipped penetrometer at four randomly selected locations within a plot. Soil PR readings were recorded upto $40 \mathrm{~cm}$ depths. The PR readings were then averaged for each plot. Field measurements of infiltration characteristics were made by using a double ring infiltrometer (Reynolds et al., 2002). The infiltrometers $25 \mathrm{~cm}$ high and with $60 \mathrm{~cm}$ and $30 \mathrm{~cm}$ diameters of outer 
and inner rings, respectively, were inserted to $10 \mathrm{~cm}$ depth with the remaining $15 \mathrm{~cm}$ above ground. Soil moisture storage was determined by adding amount of water available in different soil layers at 75 and 145 days after sowing.

\subsection{Rice and Wheat Yield and Statistical Analysis}

The straw and grain yield of wheat and rice was recorded separately for each treatment plot and end yield was calculated as $\mathrm{t} \mathrm{ha}^{-1}$. Statistical analysis was performed using an analysis of variance with statistical software CPCS1 (Cheema \& Singh, 1991). Least Significant Difference (LSD) test at $\mathrm{P}<0.05$ unless otherwise mentioned.

\section{Results}

\subsection{Bulk Density and Porosity}

Soil bulk density did not varied significantly among different tillage and residue management practices in both the soils (Table 1). Maximum soil bulk density $\left(\mathrm{Mg} \mathrm{m}^{-3}\right)$ was observed in HS (1.57) followed by NT (1.56) and RT (1.55) at $0-15 \mathrm{~cm}$ soil depth in SL soil. Differences in soil bulk density were observed to be non significant even at lower soil depth i.e. $15-30 \mathrm{~cm}$ but with higher values. In LS soil maximum bulk density $\left(\mathrm{Mg} \mathrm{m}^{-3}\right) \mathrm{was}$ observed in HS (1.58) followed by RT (1.56) and NT (1.55) at 0-15 cm soil depth. However, at lower soil depth $(15-30 \mathrm{~cm})$ the trend of change in bulk density $\left(\mathrm{Mg} \mathrm{m}^{-3}\right)$ was opposite as compared to surface soil layer and maximum values was observed in NT (1.74) followed by RT (1.72) and HS (1.70). Soil porosity varied under different tillage practices. In SL soil porosity (\%) varied from 40.6 (HS) to 41.2 (RT) in 0-15 cm depth (Table 2). At subsurface depth porosity decreased to $13 \%$ as compared to surface soil. However, no change in porosity was observed at lower soil depths $(15-30 \mathrm{~cm})$ in SL soil. In LS soil maximum porosity (\%) was observed in NT (41.7) followed by RT (40.9) and HS (39.8) at 0-15 cm depth. However, at 15-30 cm depth maximum porosity was observed in HS (36.4) followed by RT (35.9) and NT (34.3).

Table 1. Effect of tillage on bulk density $\left(\mathrm{Mg} \mathrm{m}^{-3}\right)$ in sandy loam and loamy sand soils

\begin{tabular}{ccccc}
\hline \multirow{2}{*}{ Tillage practice } & \multicolumn{2}{c}{ Sandy loam } & \multicolumn{2}{c}{ Loamy sand } \\
\cline { 2 - 5 } \cline { 3 - 5 } & \multicolumn{4}{c}{ Soil depth $(\mathrm{cm})$} \\
\cline { 2 - 5 } & $0-15$ & $15-30$ & $0-15$ & $15-30$ \\
\hline NT & 1.56 & 1.71 & 1.55 & 1.74 \\
RT & 1.55 & 1.71 & 1.56 & 1.72 \\
HS & 1.57 & 1.72 & 1.58 & 1.70 \\
LSD $(<0.05)$ & $\mathrm{NS}$ & $\mathrm{NS}$ & $\mathrm{NS}$ & $\mathrm{NS}$ \\
\hline
\end{tabular}

Table 2. Effect of tillage on porosity (\%) in sandy loam and loamy sand soils

\begin{tabular}{ccccc}
\hline \multirow{2}{*}{ Tillage practice } & \multicolumn{2}{c}{ Sandy loam } & \multicolumn{2}{c}{ Loamy sand } \\
\cline { 2 - 5 } \cline { 3 - 5 } & $0-15$ & $15-30$ & $0-15$ & $15-30$ \\
\cline { 2 - 5 } & 40.8 & 35.5 & 41.7 & 34.3 \\
NT & 41.2 & 35.3 & 40.9 & 35.9 \\
RT & 40.6 & 35.3 & 39.8 & 36.4 \\
HS & 0.3 & NS & 0.8 & 0.6 \\
\hline LSD $(<0.05)$ & & & & \\
\hline
\end{tabular}

\subsection{Soil Penetration Resistance (PR)}

Data pertaining to PR as affected by different tillage practices is presented in Table 3. Maximum PR (k Pa) was observed in HS (2539) followed by RT (2512) and NT (2412) in SL soil. Whereas, in LS soil, maximum PR (k $\mathrm{Pa}$ ) was observed in RT (2603) followed by HS (2537) and NT (2433). The soil depth (cm) of maximum PR was observed to be highest in HS (20.1), followed by NT (19.7) and RT (18.1) in SL. However, in LS soil maximum PR (K Pa) was recorded at 18.8, 19.0 and $20.5 \mathrm{~cm}$ soil depths in RT, HS and NT, respectively. However, no 
significant differences were observed in PR values in both the soils.

Table 3. Effect of tillage on penetration resistance ( $\mathrm{K} \mathrm{Pa}$ ) in sandy loam and loamy sand soils

\begin{tabular}{cccccc}
\hline \multirow{2}{*}{ Tillage practice } & \multicolumn{2}{c}{ Sandy loam } & & \multicolumn{2}{c}{ Loamy sand } \\
\cline { 2 - 3 } \cline { 5 - 6 } & Soil depth $(\mathrm{cm})$ & PR $(\mathrm{K} \mathrm{Pa})$ & & Soil depth $(\mathrm{cm})$ & PR $(\mathrm{K} \mathrm{Pa})$ \\
\hline NT & 19.7 & 2412 & & 20.5 & 2433 \\
RT & 18.1 & 2512 & & 18.8 & 2603 \\
HS & 20.1 & 2539 & & 19.0 & 2537 \\
LSD $(<0.05)$ & $\mathrm{NS}$ & $\mathrm{NS}$ & & $\mathrm{NS}$ & $\mathrm{NS}$ \\
\hline
\end{tabular}

\subsection{Infiltration Characteristics and Soil Profile Moisture Storage}

Data pertaining to changes in infiltration characteristics with tillage practices is given in Table 4. Maximum initial infiltration rate $\left(\mathrm{cm} \mathrm{hr}^{-1}\right)$ was observed in RT (8.0) followed by NT (7.8) and HS (4.6) in SL soil. Whereas, in LS, maximum initial infiltration rate $\left(\mathrm{cm} \mathrm{hr}^{-1}\right)$ was observed in RT (19.6) followed by NT (14.9) and HS (12.4) The final infiltration rate $\left(\mathrm{cm} \mathrm{hr}^{-1}\right)$ was observed to be maximum in NT (0.3), followed by HS (0.2) and RT (0.1) in SL soil. In LS soil, maximum final infiltration rate $\left(\mathrm{cm} \mathrm{hr}^{-1}\right)$ was recorded under HS (0.8) followed by NT (0.7) and RT (0.5). Significant differences in soil moisture storage were observed among different tillage practices (Table 5). Maximum soil moisture storage ( $\mathrm{mm}$ ) was observed under HS (240 and 135) followed by NT (210 and 110 ) and RT (180 and 90) at 75 and 145 days after sowing respectively in SL soil. Similar soil moisture storage trend under different tillage practices was observed in LS soil.

Table 4. Initial and final infiltration rate $\left(\mathrm{cm} \mathrm{hr}^{-1}\right)$ as affected by tillage in sandy loam and loamy sand soils

\begin{tabular}{cccccc}
\hline \multirow{2}{*}{ Tillage practice } & \multicolumn{2}{c}{ Sandy loam } & & \multicolumn{2}{c}{ Loamy sand } \\
\cline { 2 - 3 } \cline { 5 - 5 } \cline { 5 - 5 } & IIR $\left(\mathrm{cm} \mathrm{hr}^{-1}\right)$ & FIR $\left(\mathrm{cm} \mathrm{hr}^{-1}\right)$ & & IIR $\left(\mathrm{cm} \mathrm{hr}^{-1}\right)$ & FIR $\left(\mathrm{cm} \mathrm{hr}^{-1}\right)$ \\
\hline NT & 7.8 & 0.3 & & 14.9 & 0.7 \\
RT & 8.0 & 0.1 & & 19.6 & 0.5 \\
HS & 4.6 & 0.2 & & 12.4 & 0.8 \\
LSD $(<0.05)$ & 2.7 & NS & & 3.1 & 0.2 \\
\hline
\end{tabular}

$\mathrm{IIR}=$ Initial infiltration rate; FIR $=$ Final infiltration rate.

Table 5. Profile moisture storage ( $\mathrm{mm})$ as affected by tillage in sandy loam and loamy sand soils

\begin{tabular}{cccccc}
\hline \multirow{2}{*}{ Tillage practice } & \multicolumn{2}{c}{ Sandy loam } & & \multicolumn{2}{c}{ Loamy sand } \\
\cline { 2 - 3 } \cline { 5 - 6 } & 75 DAS & 145 DAS & & 75 DAS & 145 DAS \\
\hline NT & 210 & 110 & & 140 & 110 \\
RT & 180 & 90 & & 120 & 90 \\
HS & 240 & 135 & & 165 & 125 \\
LSD $(<0.05)$ & 35 & 30 & & 20 & 25 \\
\hline
\end{tabular}

DAS $=$ Days after sowing.

\subsection{Rice and Wheat Yield}

Data pertaining to rice and wheat yield as affected by tillage practices is presented in Table 6. Maximum rice straw yield $\left(\mathrm{t} \mathrm{ha}^{-1}\right)$ was observed in RT (9.3) followed by HS (9.2) and NT (7.6) in SL soil. Whereas, in LS, maximum rice straw yield $\left(\mathrm{t} \mathrm{ha}^{-1}\right)$ was observed in HS (5.1) followed by NT (4.3) and RT (4.2). However, the rice yield $\left(\mathrm{t} \mathrm{ha}^{-1}\right)$ was observed to be maximum in RT (8.0), followed by NT (7.5) and HS (7.0) in SL soil. In LS soil, maximum rice yield ( $\mathrm{t} \mathrm{ha}^{-1}$ ) was recorded in RT (6.5) followed by NT (5.8) and HS (5.5). The wheat straw 
yield $\left(\mathrm{t} \mathrm{ha}^{-1}\right)$ ranged from 4.9 (NT) to 5.9 (HS) in SL soil, however, this range was 4.0 (NT) to 5.2 (HS) in LS soil. The wheat grain yield $\left(\mathrm{t} \mathrm{ha}^{-1}\right)$ was observed to be maximum in HS (4.5), followed by RT (4.0) and NT (3.9) in SL soil. In LS soil, the wheat grain yield was recorded to be maximum in HS (3.6) followed by RT (3.0) and NT (2.7).

Table 6. Effect of tillage on rice and wheat yields $\left(\mathrm{t} \mathrm{ha}^{-1}\right)$ in sandy loam and loamy sand soils

\begin{tabular}{|c|c|c|c|c|c|c|c|c|}
\hline \multirow{3}{*}{ Tillage practice } & \multicolumn{4}{|c|}{ Sandy loam } & \multicolumn{4}{|c|}{ Loamy sand } \\
\hline & \multicolumn{2}{|c|}{ Rice } & \multicolumn{2}{|c|}{ Wheat } & \multicolumn{2}{|c|}{ Rice } & \multicolumn{2}{|c|}{ Wheat } \\
\hline & Straw & Grain & Straw & Grain & Straw & Grain & Straw & Grain \\
\hline NT & 7.6 & 7.5 & 4.9 & 3.9 & 4.3 & 5.8 & 4.0 & 2.7 \\
\hline RT & 9.3 & 8.0 & 5.3 & 4.0 & 4.2 & 6.5 & 4.1 & 3.0 \\
\hline HS & 9.2 & 7.0 & 5.9 & 4.5 & 5.1 & 5.5 & 5.2 & 3.6 \\
\hline $\operatorname{LSD}(<0.05)$ & 1.4 & NS & 0.6 & NS & NS & NS & 0.5 & NS \\
\hline
\end{tabular}

\section{Discussion}

Tillage significantly affects soil physical characteristics and crop yields. Soil moisture storage was observed to maximum under HS due to mulching effect, interception of rainfall and reduction of runoff caused by loose straw and standing rice stubbles. These results are consistent with those reported by others researchers (Mahboubi et al., 1993; Diaz-Zorita et al., 2002; Bhattacharyya et al., 2008). Minimum soil profile moisture storage was observed under NT where whole of the crop residue was removed after paddy harvesting. Due to favorable moisture conditions, wheat yield was observed to be maximum under HS. As rice was transplanted under puddled soil conditions, thus, no significant residual effects of tillage imposed in wheat was observed in rice. Due to no till soil conditions and less pulverization the bulk density was observed to be higher under HS in surface soil layer. Similarly, Ram et al. (2010) reported higher bulk density in conservation tillage due to undisturbed soil surface leading to soil compaction. The effect of tillage and residue management practices on PR was observed to be non significant with slightly greater value under HS in SL soil. Similarly, Jabro et al. (2008) observed higher PR under conservation tillage due to undisturbed or unloosened condition of soil. The water transmission characteristics also did not show any significant change due to tillage and residue management practices, the reason may be short period of imposing different tillage and residue management practices in experiment. In long term experiment, changes may be expected in PR as well as water transmission properties of the soil.

\section{References}

Aniekwe, M. A. N., Mbah, C. N., Ezeaku, P. I., \& Onyia, V. N. (2007). Tillage and plastic mulch effects on soil properties and growth and yield of cocoyam (Colocasia esculenta) on an Ultisol in southeastern Nigeria. Soil Till. Res., 93, 264-272. http://dx.doi.org/10.1016/j.still.2006.04.007

Anikwe, N. L., Okereke, O. U., \& Anikwe, M. A. N. (2004). Modulating effect of black plastic mulch on the environment, growth and yield of cassava in a derived savannah belt of Nigeria. Tropicultura., 22, 185-190.

Azooz, H., \& Arshad, M. A. (1996). Soil Infiltration and hydraulic conductivity under long-term no-tillage and conventional tillage systems. Can. J. Soil Sci., 76, 143-152. http://dx.doi.org/10.4141/cjss96-021

Bauder, A., \& Black, A. L. (1981). Soil carbon, nitrogen, and bulk density comparisons in two cropland tillage systems after 25 years and in virgin grassland. Soil Sci. Soc. Am. J., 45, 1166-1170. http://dx.doi.org/10.2136/sssaj1981.03615995004500060032x

Bhatt, R., \& Khera, K. L. (2006). Effect of tillage and mode of straw mulch application on soil erosion in the sub-mountainous tract of Punjab, India. Soil Till. Res., 88, 107-115. http://dx.doi.org/10.1016/j.still.2005.05.004

Bhattacharyya, R., Kundu, S., Pandey, S. C., Singh, K. P., \& Gupta, H. S. (2008). Tillage and irrigation effects on crop yields and soil properties under the rice-wheat system in the Indian Himalayas. Agric. Water Manage., 95, 993-1002. http://dx.doi.org/10.1016/j.agwat.2008.03.007

Brady, N. C., \& Weil, R. R. (1999). The Nature and Properties of Soils (12th ed.). Prentice Hall, Inc., New 
Jersey.

Cameira, M. R., Fernando, F. M., \& Pereira, L. S. (2003). Soil macropore dynamics affected by tillage and irrigation for a silty loam alluvial soil in southern Portugal. Soil Tillage Res., 70, 131-140. http://dx.doi.org/10.1016/S0167-1987(02)00154-X

Cannel, R. Q. (1985). Reduced tillage in north-west Europe - A review. Soil Tillage Res., 5, $129-177$. http://dx.doi.org/10.1016/0167-1987(85)90028-5

Carman, K. (1997). Effect of different tillage systems on soil properties and wheat yield in middle Anatolia. Soil Till. Res., 40, 204-207. http://dx.doi.org/10.1016/S0167-1987(96)01059-8

Carter, M. R. (1996). Characterization of soil physical properties and organic matter under long-term primary tillage in a humid climate. Soil Tillage Res., 38, 251-263. http://dx.doi.org/10.1016/S0167-1987(96)01023-9

Cetin, M., Ozgoz, E., \& Gurhan, R. (2005). The effect of different tillage systems on some physico-mechanical properties of the soil at second Crop production University of Gazi Osmanpasa. J. Agric. Faculty., 22, 31-36.

Chang, C., \& Lindwall, C. W. (1990). Comparison of the effect of long term tillage and crop rotation on physical properties of a soil. Cana. Agric. Engineering, 32, 53-55.

Cheema, H. S., \& Singh, B. (1991). Software statistical package CPCS-1. Department of Statistics, PAU, Ludhiana.

Chintala, R., McDonald, L. M., \& Bryan, W. B. (2012a). Effect of soil water and nutrients on productivity of Kentucky bluegrass systems in acidic soils. J. Plant Nut., 35, 288-303. http://dx.doi.org/10.1080/01904167.2012.636131

Chintala, R., McDonald, L. M., \& Bryan, W. B. (2012b). Optimization of water potential and nutrient levels for Kentucky bluegrass-white clover mixture on acidic soils. Biotech. Agron. Soc. Envir., 16, 167-177.

Dao, H. T. (1993). Tillage and winter wheat residue management effects on water infiltration and storage. Soil Sci. Am. J., 57, 1586-1595. http://dx.doi.org/10.2136/sssaj1993.03615995005700060032x

Diaz- Zorita, M., Duarte, G., \& Grove, J. (2002). A review of no till systems and soil management for sustainable crop production in the sub-humid and semi arid Pampas of Argentina. Soil Till, Res., 65, 1-18. http://dx.doi.org/10.1016/S0167-1987(01)00274-4

Ehlers, W. (1975). Observations of earthworm channels and infiltration on tilled and untilled loess soil. Soil Sci., 119, 242-249. http://dx.doi.org/10.1097/00010694-197503000-00010

Frede, H. G., Beisecker, R., \& Gath, S. (1994). Long-term impacts of tillage on the soil ecosystem. J. Plant Nutr. Soil Sci., 157, 197-203.

Gajri, P. R., Arora, V. K., \& Chaudhary, M. R. (1994). Maize growth, response to deep tillage, straw mulching and farmyard manure in coarse textured soils of N.W. India. Soil Use Manag., 10, 15-20. http://dx.doi.org/10.1111/j.1475-2743.1994.tb00451.x

Ghuman, B. S., \& Sur, H. S. (2001). Tillage and residue management effects on soil properties and yields of rainfed mazie and wheat in a subhumid subtropical climate. Soil Till. Res., 58, 1-10. http://dx.doi.org/10.1016/S0167-1987(00)00147-1

Glab, T., \& Kulig, B. (2008). Effect of mulch and tillage system on soil porosity under wheat (Triticum aestivum). Soil Till. Res., 99, 169-178. http://dx.doi.org/10.1016/j.still.2008.02.004

Hajabbasi, M. A., \& Hemmat, A. (2000). Tillage impacts on aggregate stability and crop productivity in a clay-loam soil in central Iran. Soil Till. Res., 56, 205-12. http://dx.doi.org/10.1016/S0167-1987(00)00140-9

Hammel, J. E. (1989). Long-term tillage and crop rotation effects on bulk density and soil impedance in northern Idaho. Soil Sci. Soc. Am. J., 53, 1515-1519. http://dx.doi.org/10.2136/sssaj1989.03615995005300050036x

Hermawan, B., \& Bomke, A. A. (1997). Effects of winter cover crops and successive spring tillage on soil aggregation. Soil Till. Res., 44, 109-120. http://dx.doi.org/10.1016/S0167-1987(97)00043-3

Hussain, I, Olson, K. R., \& Siemens, L. C. (1998). Long-term tillage effects on physical properties of eroded soil. Soil Sci., 163, 970-981. http://dx.doi.org/10.1097/00010694-199812000-00007

Iqbal, M., Hassan, A. U., Ali, A., \& Rizwanullah, M. (2005). Residual effect of tillage and farm manure on some soil physical properties and growth of wheat (Triticum aestivum L.). Int. J. Agri. Biol., 7, 54-57. 
Jabro, J. D., Sainju, L. I., Stevens, W. B., \& Evans, R. G. (2008). Carbon dioxide flux as affected by tillage and irrigation in soil converted from perennial forages to annual crops. J. Environ. Manage., 88, 1478-1484. http://dx.doi.org/10.1016/j.jenvman.2007.07.012

Kanwar, R. S. (1989). Effect of Tillage Systems on the Variability of Soil Water Tensions and Soil Water Content. Trans. ASAE, 32, 605-610. http://dx.doi.org/10.13031/2013.31045

Keshavarzpour, F., \& Rashidi, M. (2008). Effect of different tillage methods on soil physical properties and crop yield of watermelon (Citrullus vulgaris). World Appl. Sci. J., 3, 359-364.

Khan, F. U. H., Tahir, A. R., \& Yule, I. J. (2001). Intrinsic implication of different tillage practices on soil penetration resistance and crop growth. Int. J. Agri. Biol., 3, 23-26.

Khurshid, K., Iqbal, M., Arif, M. S., \& Nawaz, A. (2006). Effect of tillage and mulch on soil physical properties and growth of maize. Int. J. Agric. Biol., 8, 593-596

Kumar, S., Nakajima, T., Mbonimpa, E. G., Gautam, S., Somireddy, U. R., Kadono, A., ... Fausey, N. (2014). Long-term tillage and drainage influences on soil organic carbon dynamics, aggregate stability, and carbon yield. Soil Sci. Pl. Nut., 1, 108-118. http://dx.doi.org/10.1080/00380768.2013.878643

Logsdon, S. D., Kaspar, T. C., \& Cambardella, C. A. (1999). Depth incremental soil properties under no-tillage or chisel management. Soil Sci. Soc. Am. J., $\quad 63, \quad 197-200$. http://dx.doi.org/10.2136/sssaj1999.03615995006300010028x

Mahboubi, A. A., Lal, R., \& Fausey, N. R. (1993). Twenty-eight years of tillage effects on two soils in Ohio. Soil Sci. Soc. Am. J., 57, 506-512. http://dx.doi.org/10.2136/sssaj1993.03615995005700020034x

Ogban, P. I., Ekanem, T. P., \& Etim, E. A. (2001). Effect of mulching methods on soil properties and growth and yield of maize in Southeastern Nigeria. Trop. Agric., 78, 82-89.

Ogban, P. I., Ogunewe, W. N., Dike, R. I., Ajaelo, A. C., Ikeata, N. I., Achumba, U. E., \& Nyong, E. E. (2008). Effect of tillage and mulching practices on soil properties and growth and yield of cowpea (Vigna Unguiculata L.) in Southeastern Nigeria. J. Trop. Agri. Food, Envir. Exte., 7, 118-128.

Ozpiner, S., \& Cay, A. (2005). Effects of minimum and conventional tillage systems on soil properties and yield of winter wheat in clay-loam in the Canakkale region. Turk. J. Agric. Forest., 29, 9-18.

Prasad, R. (2014). Using nitrogen and phosphorus budgets as effective tools for assessing nitrogen and phosphorus losses from agricultural systems (Ph.D. Diss.). Univ. of Florida, Gainesville.

Ram, H., Kaler, D. S., Singh, Y., \& Kumar, K. (2010) Productivity of maize-wheat system under different tillage and crop establishment practices. Soil Till. Res., 113, 48-54.

Sarkar, S., \& Singh, R. S. (2007). Interactive effect of tillage depth and mulch on soil temperature, productivity and water use pattern of rainfed barley (Hordium vulgare L.). Soil Till. Res., 92, 79-86. http://dx.doi.org/10.1016/j.still.2006.01.014

Sarkar, S., Paramanick, M., \& Goswami, G. B. (2007). Soil temperature, water use and yield of yellow sarson (Brassica napus L. var. glauca) in relation to tillage intensity and mulch management under rainfed lowland ecosystem in eastern India. Soil Till. Res., 93, 94-101. http://dx.doi.org/10.1016/j.still.2006.03.015

Sen, A., Sharma, S. N., Singh, R. K., \& Pandey, M. D. (2002). Effect of different tillage systems on the performance of wheat: Exth Bull (pp. 121-22). CCS Haryana Agricultural University, Hisar, India.

Shipitato, M. J., Dick, W. A., \& Edwards, W. M. (2000). Conservation tillage and macrospore factors that affect water movement and the fate of chemicals. Soil Till. Res., 53, 167-183. http://dx.doi.org/10.1016/S0167-1987(99)00104-X

Sieling, K., Schroder, H., Finck, M., \& Hanus, H. (1998). Yield, N uptake, and apparent N-use efficiency of winter wheat and winter barley grown in different cropping systems. J. Agric. Sci., 131, $375-87$. http://dx.doi.org/10.1017/S0021859698005838

Talaat, A. M. (2009). Assessment of infiltration rate parameters for water management in reclaimed area. Res. $J$. Agri. and Bio. Sci., 5, 223-234.

Tessier, S., Peru, M., Dyck, F. B., Zentner, R. P., \& Campbell, C. A. (1990). Conservation tillage for spring wheat production in semi-arid Saskatchewan. Soil Till. Res., 18, $73-89$. http://dx.doi.org/10.1016/0167-1987(90)90094-T

Tripathi, S. C., \& Chauhan, D. S. (2000). Evaluation of fertilizer and seed rate in wheat under different tillage 
conditions after transplanted rice. Ind. J. Agric. Sci., 70, 574-76.

Yuecun, M. A., Hongling, Q., Chunmei, Y., Wangsheng, G. A. O., Hongsheng, Z., Peng, S., ... Xiangdong, L. (2008). Dynamics of soil water content under different tillage systems in agro-pastural eco-zone. Front. Agric. China., 2, 208-215. http://dx.doi.org/10.1007/s11703-008-0034-2

\section{Copyrights}

Copyright for this article is retained by the author(s), with first publication rights granted to the journal.

This is an open-access article distributed under the terms and conditions of the Creative Commons Attribution license (http://creativecommons.org/licenses/by/3.0/). 